\title{
Training the Creative Librarian in the Age of Technological Advancement
}

\author{
*Onuoha, Uloma D., Unegbu, Vincent E., Ukachi, Ngozi, B. \\ Babcock University, Ilishan Remo, Ogun State, Nigeria \\ *ud_onu@yahoo.com
}

\begin{abstract}
This paper examined the changes in librarianship brought about by advancement in technology especially as it relates to new work functions expected of librarians. The major objective of the study was to identify the role of curriculum in the training of creative and innovative librarians. The paper demonstrates that curriculum re-assessment in library schools is necessary for the mastery of knowledge needed for problem solving on which the basis of creativity and innovation lies. As a result, the paper concludes by recommending amongst others, that the curriculum of library schools be reviewed taking into consideration the current job requirements of librarians as this would empower librarians apply knowledge to problem solving, thereby bringing about creativity and innovation in library services. Library administrators should also encourage innovation and creativity by ensuring an enabling environment where staff is free to experiment with technology without fear of reproof.
\end{abstract}

Keywords: Creativity; Curriculum; ICT; Innovation; Librarianship; Technological advancement, Training

\section{Introduction}

The training of Librarians in Nigeria has come a long way starting with the establishment of the first library school at the then university college, Ibadan in 1960 (Saleh, 2011). Since then the country has produced countless men and women to oversee the various types of libraries in the country. Adah (2010), however, notes that the erstwhile image of a traditional librarian is that of a man or woman occupying a seat in the library building with the task of acquiring, organising, preserving printed documents and assisting readers in locating needed information. This image was not just restricted to librarians in Nigeria as Pugh (2005) states that until the late 1960s and early1970s when the use of computers for housekeeping techniques expanded; there had been no significant change in libraries for 100 years. Changes in libraries have been attributed mostly to advancement in technology (Troll, 2001; Ifidion \& Ifidion, 2007; Madu, 2008; Adomi, 2008). As noted by Youngok (2006) traditional collections are giving way to hybrid collections. Anyira (2011) also points out that the work done in libraries worldwide have changed with the emergence of concepts such as hybrid library, digital library, virtual library, paperless library, etc. These changes according to Youngok (2006) come along with their peculiar characteristics despite sharing the same purpose of preserving, organizing and distributing information resources as in the case of traditional libraries. Ifidion \& Ifidion (2007), affirm that these changes have altered the entire structure of library and information services forcing library managers to re-think the strategic fundamentals of their service concept. Lancaster (1997) puts the picture into better perspective when he notes that libraries must continue to organize the universe of resources in ways that are likely to be of value to their user communities in order to justify its existence in the electronic world.

Although libraries in Nigeria are embracing the use of ICT in service delivery, Ademodi \& Adepoju (2009) noted with dismay the low level of computer skills among librarians. Corroborating this, Adomi \& Anie (2006) in their research on the computer literacy skills of professionals in Nigerian University libraries concluded that librarians' use of computer and technology is still maturing. The adoption of ICT without adequate technological knowledge is, however, not without its consequences as Johnson (1991) for instance, attributes the failure of most library automation projects in developing countries to insufficient knowledge of information technology. Hashim \& Mokhtar (n.d.) affirm that fitting into the technological environment will certainly not be a short-term project stressing that the value of curriculum and instructional design cannot be denied. Curriculum according to Wiles (2005) is a planned programme of learning opportunities to achieve broad educational goals and related objectives. Osanyin, Ige \& Adebayo (2006) explain that curriculum consists of the continuous chain of activities necessary for translating educational goals into concrete activities, materials, and observable behavioural change. Curriculum, therefore, can be said to be the backbone of professional development as the acquisition of knowledge to excel in one's profession starts from acquiring the necessary training in form of education. Indeed, Jain, Kaur \& Babbar (2007) concur that curriculum is the core of the reform. The training of creative and 
innovative librarians in the age of technology will, therefore, require a re-think in the curriculum of library schools.

Advancement in information technology has brought about changes in traditional librarianship as librarians are now faced with the task of adapting to the technological environment with Information Communication Technologies (ICT) in service provision. While this is, no doubt, a welcome development; it, however, demands an understanding of new technologies and calls for innovation and creativity which may have been lacking in the training of the librarian and thus raises the question: How can librarians be trained to master the use of technology in new and creative ways?

The main objective of this study is to find out how library school curriculum can be used in the training of creative and innovative librarians. Specific objectives are to:

- Highlight the importance of technology in the creativity and innovation of librarians.

- Postulate changes in current library and information science (LIS) curriculum.

\section{The librarian in a technological age}

The word librarian has been defined differently in recent times. Salaam \& Onifade (2009) describe a librarian as someone who has obtained a first degree in library and information science or in any subject field and a master's degree in library and information science. To Limbachiva (2010), a librarian is an innovative person who develops various systems for arranging information, provides services that assist and instruct people in the most efficient ways to identify and access any needed information. Going from both definitions, a librarian is someone who has gone beyond the training of the library school and is capable of creativity in the cause of carrying out his or her duties. Traditionally, five main tasks were part of a librarian's job profile: (1) making information available, (2) keeping materials collection up-to-date, (3) arranging and storing information, (4) assisting users in finding information, and (5) exchanging information with other libraries (Bruijnzeels, Bitter-Rijpkema \& Verjans, 2010). These tasks were centred mostly on having an up-to-date collection, which was made available to users in the physical library. Librarians were, therefore, constrained to work within the physical walls of the library.

In the technological age, however, the library is more than a physical place as library services extend beyond the physical library space to virtual environment (Martell, 2000). Traditional ownership of print resources is supplemented with access to electronic resources (Stewart, 2000). Consequently, librarians' now have to work in an environment where they are not only faced with print materials but electronic resources as well. Indeed, Kaur \& Sharda (2010) affirm that librarians are playing the role of electronic middlemen. No wonder then that Putman (2005) asserts that the librarian in the technological age is an expert in using sophisticated online search engines, is critical about the quality of information (sources), and enters into innovative relationships with the public in search of new meanings that fit with the public's needs. Considering the new roles, Nofsinger (2003) points out that librarians would have to deal with sensitive political and social issues, including censorship, the digital divide, pornography, copyright, privacy and confidentiality concerns, intellectual freedom, and electronic archiving of resources. All of which calls for a look into the existing curriculum in library schools. The roles played by librarians in the technological age are also reflected in current job titles. Mach (2003) states that current job titles for librarians now include: Access Services Librarian, Automation and Cataloguing Librarian, Business Librarian, Computer Services Librarian, Electronic Resources Cataloguer, Development and Community Relations Officer etc. These new titles according to Hazeri, Sarrafzadeh \& Martin (2007); Hashim \& Mokhtar (n. d.) require professional skills for a commercial context, communication skills, management skills, team-working skills and IT skills. Corroborating this fact, Nwalo (2000) as cited in Edegbo (2011) admits that the challenging roles facing librarians requires the acquisitions of new resources, expertise and careful planning.

Need for creativity and innovation among librarians: In order to cope with the changing requirements of librarianship, there is need to prevent doing today's job with yesterday's tools and concepts. It is on the basis of this that Hall (2003) asserts that the professional librarian must be a problem solver, someone who is able to see the whole picture and how the pieces fit together. The librarian should not just be knowledgeable but creative and innovative. Library and Information Association of Mauritius (LIAM) (2009) defines creativity as problem identification and idea generation, whereas innovation refers to idea selection and its development and commercialisation. Deiss (2004) points out that there is a connection between creativity and innovation. According to her creativity is the act of generating new ideas and new 
perspectives. Innovation, on the other hand, occurs when creativity is applied and a product or service results. From the definitions, it can be deduced that simply having knowledge may not be all that is required to re-invent the library. Knowledge must be put into good use through problem solving. Librarians must identify the challenges facing them while mapping out strategies for resolving them.

Koveckienè (2012) notes that creativity must have novelty, originality, usefulness and value. In order words, creativity and innovation must add something of value to the library. Bells (2008) argues that acts of creativity in librarianship need not depend on grandiose programs or large-scale budgets as the author maintains that creativity does not necessarily involve fiercely original ideas but simple new ways to approach a well-known service. Also, LIAM (2009) points out that innovation in libraries may involve the following initiatives:

- The discovery of unmet user needs

- The introduction of new services or the retooling of traditional services resulting in a better user experience

- Creative collaboration among libraries or between libraries and other institutions

- Explorations of the future of libraries

- Implementing new technologies to improve and extend library services to meet user needs

- Redefining processes that encourage finding new and better ways to make library collections and facilities more useful

- Incorporating best practices from foreign libraries wherever possible.

In order to encourage creativity and innovation, Farkas (2013) argues that library administration has a role to play through the following: encourage staff to learn and play; encouraging network building; developing a risk -tolerant culture; tying innovative ideas to mission / goals of the library and improving communication with users. Although library administrators can boost creativity and innovation among staff, nevertheless, individuals owe it upon themselves to acquire the needed skill, thinking ability and motivation needed to successfully carry out projects. As noted by Diaz (2008), creativity requires manipulation of past and present knowledge. Pungitore (1995) argues that based on their knowledge of what is possible in today's high technology world and their awareness of successful technological applications in other libraries, professional librarians may have a vision of where the library should be heading. Individuals must, therefore, examine their areas of strength and weakness; identify needed skills and how these skills can bring positive change to library procedures. In addition, Sahlberg (2009) points out that individuals who aspire to be creative must be knowledgeable and prepared to be seen as strange or wrong by those around them. In order words, creative people must conquer the fear of failure, they must be able to accept mistakes and not give up easily on their goals.

\section{The role of curriculum in creativity and innovation}

In the opinion of Bronson \& Merryman (2010), the creative process is not just about freedom from concrete facts; rather it is about fact-finding and deep research. Similarly, Diaz (2008) argues that creativity and innovation require a wide range of knowledge on a wide range of subjects with a wide range of approaches. Altrichter (2005) in like manner, affirms that innovation requires changes in action and attitude, which can only result from re-learning competencies. It can be deduced from the foregoing assertions that innovation requires educational training in order to bring about new competencies and attitude. On, the other hand, curriculum refers to the total courses of study offered by a school to the students during their training. It is a particular body of course, generally linked with an orderly plan and progression (Willgoose, 1974). In the view of Stenhouse (1975), curriculum is a hypothesis, a starting point for reflection and development done by responsible professionals. The curriculum, therefore, is a fundamental part of any education or training programme largely because it provides not only a list of courses or modules offered in a programme, but it also gives information on content, purpose, method, time/duration, trainers and location or situation of a programme or course all of which are essential in a successful dispensation of manpower training and education (Ocholla, 2000). The importance of curriculum is stressed by Stenhouse (1975) who argues that whenever re-learning is meant for stabilised skills and action patterns, then re-learning must be based on action and interaction over an extended time span. Learning over an extended span is, however, best achieved in a school system. As noted by Mäntykangas \& Omstedt (2012) students are a resource for innovation and new thinking in library work, being young persons who can still be shaped and influenced in different ways. 
In a recent survey of the curriculum for bachelor in library science (BLS) degree in Nigeria, Saleh (2011) examined the curriculum for BLS program in five library schools. The study revealed variations in the curriculum especially with courses tagged "elective". Courses considered as "core" were, however, found to be common to all five schools. The core courses were found to be cataloguing and Classification, Collection Development, Reference, and Bibliography. Most of the respondents, also called for a review of the curriculum with a view to emphasizing more on current Information Technology courses such as Communication Systems, Database Management, System Analysis, Information Science etc. Even in schools, where information Technology courses were found to be offered, the choice of courses differed among schools. The current trend is, however, not encouraging and calls for harmonization through a reassessment of the curriculum in library schools. The re-assessment of curriculum is, however, a task, which needs critical planning by specialists taking into consideration the objectives that curriculum, intends to achieve.

Education and Training of innovative and creative librarians: The training of librarians in a technological era has been the focus of some recent studies (Malinconico, 1992; Gupta, 2001; Raju, 2003) as efforts are being made to make librarians more relevant in the age of technology. Smidt (2005) opines that education merely concentrating on traditional librarianship such as classification and knowledge organisation cannot adequately prepare students for the challenges of their future profession. This is evidenced in the study of Choi \& Rasmussen (2006) which sought to find out among thirty four digital librarians, the aspects of their work for which their education and training had not prepared them adequately. Findings from the study revealed that the most frequently mentioned tasks were related to technical aspects. These are:

- Overall understanding of the complex interplay of software,

- Lack of vocabulary to communicate to technical staff,

- Knowledge of Web-related languages and technologies,

- Web design,

- Digital imaging and formatting,

- Digital technology,

- Programming and scripting languages,

- XML standards and technologies

- Basic systems administration

In the view of Ochogwu (1990), introduction of new courses, especially those outside the confines of traditional library science such as Database Construction and Management, Planning and Financing of Information Systems is a necessary response to the multidisciplinary nature of the profession. In view of this, Taylor as cited by Ochogwu (1990) asserts that to educate librarians to think only in terms of a place called the library as we currently know that institution is to do them a disservice and probably doom them to ineffectuality.

\section{Contextual discussion}

The need for creativity and innovation among librarians in Nigeria calls for urgent attention as Johnson (1991) rightfully notes the failure of some technologically driven projects in libraries in developing countries due to insufficient knowledge of information technology. The case for Nigeria is of particular interest considering the findings of Ademodi \& Adepoju (2009); Adomi \& Anie (2006), whose studies revealed low level computer skills among librarians. The current state of computer skills among librarians in Nigeria falls below the expectation in today's environment, which is in disagreement with the assertion of Putman (2005) who noted that the librarian in the technological age is an expert in using sophisticated online search engines, is critical about the quality of information (sources), and enters into innovative relationships with the public in search of new meanings that fit with the public's needs.

The quest for creativity and innovation in a technological age demands mastery of technology, which is in agreement with Bronson \& Merryman (2010), who affirm that the creative process is about fact-finding and deep research. By implication, librarians must understand how technology works before they can manipulate it to achieve original and innovative results. Through the introduction of technologically based courses, librarians in Nigeria would acquire necessary skills needed for concept mastery, creativity and innovation, which calls for reform in the educational curriculum. This is in agreement with Stenhouse (1975) who argues that whenever re-learning is meant for stabilised skills and action patterns, then relearning must be based on action and interaction over an extended time span. The role of curriculum is 
equally supported by Mäntykangas \& Omstedt (2012) who see students as a resource for innovation and new thinking in library work, being young persons who can still be shaped and influenced in different ways. By this discussion, it would be appropriate to postulate, therefore, that there is urgent need for curriculum change and skill re-orientation among librarians in Nigeria to avert the danger of academic and professional obsolescence.

\section{Conclusion}

There is no doubt that advancement in technology has brought about changes in diverse aspects of librarianship. Technology has not only affected the types of information materials stored in libraries, it has also the services offered by the library and the skills required for offering such services. In order to cope with these changes librarians must not only acquire training necessary for understanding the use of modern technologies through planned educational curriculum, they must also discover creative ways of using technology to add value to library services.

Recommendations: Based on the foregoing, the following recommendations are suggested:

- The curriculum of library schools should be reviewed taking into consideration the current job requirements of librarians as this would empower librarians in applying knowledge to problem solving, thereby bringing about creativity and innovation in library services.

- Considering the need for creativity and innovation, librarians must be willing to take risk as they experiment with new technology.

- Librarians should not shy away from learning especially when learning entails taking courses outside the confines of traditional librarianship as this would enable them deal with the multidisciplinary nature of library work in the technological era.

- Library administrators should encourage innovation and creativity by ensuring an enabling environment where staff is free to experiment with technology without fear of reproof.

- Nigerian library association should also encourage creativity among librarians by conducting seminars and workshops that are technologically oriented.

- The National Universities Commission (NUC) as the governing body overseeing education in Nigeria should ensure the review of library curriculum to accommodate technologically based courses.

\section{References}

Adah, J. E. (2010). Electronic age: What can the college librarian do? Tincity journal of library, archival and information science, 1(2), 70-73.

Ademodi, D. T. \& Adepoju, E. O. (2009). Computer skill among librarians in academic libraries on Ondo and Ekiti States, Nigeria. Library Philosophy \& Practice. Retrieved from http://unllib.unl.edu/LPP/ademodi-adepoju.htm

Adomi, E. E. (2008). Foundations of Reference Services Benin City: Ethiopia Publishing Corporation.

Adomi, E. E. \& Anie, S. O. (2006). An assessment of computer literacy skills of professionals in Nigerian University libraries. Library Hi Tech News, 23(2), 10-14.

Altrichter, H. (2005). Curriculum implementation - limiting and facilitating factors. In: P. Nentwig \& D. Waddington (Eds.): Context based learning of science (pp.35-62). Waxmann: Münster

Anyira, I. E. (2011) One Among the Twelve: How Library Professionals Constitute a Serious Challenge to the Provision of Library Services in the $21^{\text {st }}$ Century Library Philosophy and Practice. Retrieved from http://www.webpages.uidaho.edu/ mbolin/anyira-twelve.htm

Bells, S. J. (2008). The Creativity Issue: Putting the spotlight on creative work in urban libraries. Retrieved from http://ulj.lacuny.org/index.php/past-issues/36-151/57-the-creativity-issue-putting-thespotlight-on-creative-work-in-urban-libraries-

Bronson, P. \& Merryman, A. (2010). The creativity crisis. Retrieved from http://www.thedailybeast.com/newsweek/2010/07/10/the-creativity-crisis.html.

Bruijnzeels, R., Bitter-Rijpkema, M. E. \& Verjans, S. (2010). The library school: Empowering the sustainable innovation capacity of new librarians. Retrieved from http://npsig.files.wordpress.com/2010/03/npsig_the-global-librarian_lis-school_paper.pdf.

Choi, Y. \& Rasmussen, E. (2006). What is needed to educate future digital librarians: A study of current practice and staffing patterns in academic and research libraries? Retrieved from http://www.dlib.org/dlib/september06/choi/09choi.html 
Deiss, K. (2004). Innovation and strategy: Risk and choice in shaping user cantered libraries. Library Trends, 53(1), 17-32.

Diaz, M. G. (2008). Libraries, creativity and innovation. Paper presented at conference to mark the $50^{\text {th }}$ anniversary of the central library of the European Commission Brussels, 2 December 2008. Retrieved from ec.europa.eu/libraries/doc/50ans/Libraries_creativity_and_innovation.ppt

Edegbo, W. O. (2011). Curriculum Development in Library and Information Science Education in Nigerian Universities: Issues and Prospects. Retrieved from http://www.webpages.uidaho.edu/ mbolin/edegbo.pdf

Farkas, M. (2013). Encouraging innovation in libraries. Retrieved from http://www.slideshare.net/librarianmer/encouraging-innovation-in-libraries

Gupta, D. K. (2001). Librarians' changing role in distance education: need for training. Journal of Library Administration, 32(1-2), 225-31.

Hall, D. (2003). Of babies and bathwater-hiring library staff for the $21^{\text {st }}$ century. In k. Bridges (Ed.), Expectations of librarians in the $21^{\text {st }}$ century (pp. 17-19). Westport, Connecticut: Greenwood press.

Hashim, L. B. \& Mokhtar, W. N. H. W. (n.d). Trends and issues in preparing new era librarians and information professionals. International Journal of Humanities and Social Science, 2(7), 51-156

Hazeri, A., Sarrafzadeh, M. \& Martin, B. (2007). Reflections of information professionals on knowledge management competencies in the LIS curriculum. Journal of Education for Library and Information Science, 48(3), 168-186

Ifidion, S. E. \& Ifidon, E. I. (2007). New directions in African library management. Abuja: Spectrum books limited

Jain, P. K., Kaur, H. \& Babbar, P. (2007). LIS Education in India: Challenges for students and professionals in the digital age. Retrieved from http://eprints.rclis.org/10175/1/D7505896.pdf

Johnson, J. S. (1991). Computerising information systems in developing countries: Keys to sustainable development. Pakistan Library Bulletin, 22(3), 22-30.

Kaur, H. \& Sharda, P. (2010). Role of technological innovations in improving library services International Journal of Library and Information Science, 2(1), 011-016.

Koveckiené, E. (2012). We shape our library and then our library shape us. Retrieved from http://www.lbd.lt/wp-content/uploads/2012/02/Eugenija_Koveckiene.pdf

Lancaster, F. W. (1997). Artificial Intelligence and Expert System Technologies: Prospects. In: D. Raitt (Ed.) Libraries for the New Millennium: Implications for Managers (pp19 - 37). London: Library Association Publishing

LIAM. (2009). Creativity and innovation in libraries. Retrieved from http://liamofmauritius.wordpress.com/2009/03/21/creativity-and-innovation-in-libraries/

Mach, M. (2003). Real job titles for libraries and information science professionals. Retrieved from http://www.michellemach.com/jobtitles/realjobs.html

Madu, E. C. (2008). Technology skills for information handling: New implications for the library profession in Nigeria. The information technologist, 5(1), 171-178

Malinconico, M. S. (1992). What librarians need to know to survive in an age of technology? Journal of Education for Library and Information Science, 33(3), 226-240 .

Mäntykangas, A. \& Omsted, B. (2012). Implementing innovation management in the librarians' education. Qualitative and Quantitative Methods in Libraries (QQML), 3, 295-301.

Martell, C. (2000). The disembodied librarian in the digital age, part 11. College and Research Libraries, $61,99-113$.

Nofsinger, M. M. (2003). Hiring academic reference librarians in the $21^{\text {st }}$ century. In k. Bridges (Ed.), Expectations of librarians in the $21^{\text {st }}$ century (pp. 41-44). Westport, Connecticut: Greenwood press.

Ochogwu, M. G. (1990). Alternatives in librarianship: prospects and problems for the Nigerian graduate. Journal of Education for Library \& Information Science, 30(4), 181-194.

Ocholla, D. N. (2000). Review and revision of library and information science curriculum in South Africa University and usage of follow-up study and advancement scanning methods. Retrieved from http://www.slib.ualberta.ca/cais/2000/ocholla.htm

Oesleby, L. \& Birks, J. (2003). Mere mortals need not apply. In k. Bridges (Ed.), Expectations of librarians in the $21^{\text {st }}$ century (pp. 33-36). Westport, Connecticut: Greenwood press.

Osanyin, F. A., Ige. O. \& Adebayo, A. (2006) Introduction to early childhood curriculum development. Retrieved from http://www.nou.edu.ng/noun/NOUN_OCL/pdf/EDUs/ECE\%20230.pdf

Pugh, L. (2005). Managing $21^{\text {st }}$ Century Libraries Toronto: Scarecrow press, Inc 
Pungitore, V. L. (1995). Innovation and the library: The adoption of new ideas in public libraries. West port, Connecticut: Greenwood press.

Putnam, L. (2005).Making the world safe for questions: why libraries and librarians are needed now more than ever. Public Libraries, 44(2), 86-7.

Raju, J. (2003). Never the twain shall meet? : Professional and paraprofessional LIS education and training in a changing information environment. Retrieved from: http://ir.dut.ac.za/bitstream/handle/10321/392/Raju_2003.pdf?sequence=1

Sahlberg, P. (2009). Creativity and innovation through lifelong learning. Lifelong Learning in Europe, 14(1), 53-60.

Salaam, M. 0. \& Onifade, F. N. (2009). Academic status and the doctoral degree requirement for promotion of librarians in Nigerian university libraries. Retrieved from http://www.webpages.uidaho.edu/ mbolin/salaam-onifade.htm

Saleh, A. G, (2011). Educators' perspective on library education in Nigeria. Retrieved from http://www.webpages.uidaho.edu/ mbolin/gambo.htm.

Smidt, J. K. (2005). The Cultural Dimension in Library Education. Retrieved from http://archive.ifla.org/IV/ifla71/papers/049e-Smidt.pdf.

Stenhouse, L. (1975). An introduction to curriculum research and development. London: Heinemann

Stewart, L. A. (2000) Choosing between print and electronic sources: The selection dilemma. The reference librarians, 71, 79-97.

Troll, D. A. (2001). How and why libraries are changing. Retrieved from http://www.diglib.org/use/whitepaper.htm.

Wiles, J. (2005). Curriculum essentials: A resource for educators. Boston: Pearson

Willgoose, C. E. (1974). The curriculum in physical education. Englewood N. J. I. Prentice Hall Inc.

Youngok, C. (2006). What is needed to educate future digital librarians? D-Lib Magazine, 12(9), Sept. Retrieved Nov., 17, 2008 from http://www.dlib.org/dlibseptember06/choi.html. 